\title{
Preliminary Observations on the Relative Importance of the various Factors Responsible for the Death of Fishes in Polluted Waters.
}

\author{
By
}

Hem Singh Pruthi, M.Sc.(Punjab), Ph.D.(Cantab.),

Assist. Supt. Zoological Survey of India; Fellow, International Education Board.

\section{INTRODUCTION.}

W ITH the growth of modern industry the problem of the influence of polluted waters on the bionomics of fishes is becoming very important. Fortunately, biologists anticipated this and many works on the subject have appeared, especially during the last twenty-five years. The polluting substances can be divided into two main classes, namely, (i) those that are directly poisonous to organisms, e.g. gas liquor, sulphites, oils, etc., and (ii) those that give rise to poisonous substances or otherwise make the water undesirable after putrefying, e.g. organic matter in solution and the decomposing bodies of plants and animals. The substances in the first category act in a relatively straightforward manner, and numerous investigators have studied them from several aspects (Shelford, ' 17 ; Matthews, '04; Powers, Wells, '15, etc.) ; it is with regard to those in the second class that many questions are yet unsettled and the present communication deals. We roughly know that the effect of the putrefying substances is to increase the hydrogen ion concentration and decrease the oxygen content of water. It has also been suggested that the byproducts of putrefaction themselves may be poisonous to animals. It is still an open question as to which of these factors is chiefly responsible for the death of fish; some investigators emphasize the influence of hydrogen ion concentration, others the importance of the deficiency of oxygen, and so on. One reason for this state of things seems to be that practically no systematic attempt has been made so far to isolate the various factors, and note their influence on the organisms separately. Therefore it was thought desirable to undertake a study on these lines, and some preliminary experiments have been performed, which are reported in the following pages.

A short bibliography of papers concerning factors affecting freshwater life is given at the end of this communication. 


\section{Material and Methods.}

The freshwater fish, Gasterosteus aculeatus, the common " stickleback," found round about Plymouth, was chosen for the experiments. It is quite a hardy species. This selection is against the suggestion of Shelford ('18), who thinks that a sensitive individual should be taken for such investigations. But in the opinion of the writer, a hardy species affords a more definite and hence more reliable reaction. Moreover, if a certain factor is found to be toxic to a strong race, it should be all the more toxic to sensitive ones, and therefore have a wider application.

The average weight of the above fish was $0 \cdot 8-1 \cdot 2 \mathrm{gms}$. ; some specimens weighed as much as $1.8 \mathrm{gms}$. Fishes weighing $0 \cdot 30-1.5 \mathrm{gms}$. behaved similarly, and all the experiments were performed on them; those below 0.30 gms. or above 1.5 gms. died rather quickly.

To start with, three substances, all proteins, namely, peptone, albumen of eggs, and casein of milk, have been examined as putrefying substances.

The hydrogen ion concentration determinations were made by the colorimetric methods. The oxygen content was measured by Winkler's method. The "alkali reserve" was determined by titrating with $0.01 \mathrm{~N} . \mathrm{H}_{2} \mathrm{SO}_{4}$, using methyl orange as indicator.

\section{EXPERIMENTAL.}

\section{Optimum Hydrogen Ion Concentration and $\mathrm{CO}_{2}$ Pressure.}

On an average the $\mathrm{pH}$ of the waters in which sticklebacks were found in the field was 7.5-8.0 (not corrected for the salt error). The alkali reserve of these waters was $0.0045 \mathrm{~N}$. In the Laboratory these fishes lived quite comfortably between $\mathrm{pH} 6 \cdot 0-8 \cdot 5$. Outside this range, an increase on the acid side was more harmful than on the alkaline one. In water at $\mathrm{pH} 4.5$ " stickles" died in about twelve hours, at $\mathrm{pH} 3.0$ they did so within three quarters of an hour.

Jewell ('24) found several freshwater fishes flourishing in waters having $\mathrm{pH} 4 \cdot 4$.

As regards the pressure at which $\mathrm{CO}_{2}$ becomes harmful it was noticed that as long as the concentration of this gas was not above $10 \cdot 0-13 \cdot 0$ c.c. per litre the fish did not suffer any harm. Many freshwater fishes have been found to withstand even a higher concentration of $\mathrm{CO}_{2}$, up to $40-50$ c.c. per litre (Reuss, '10 ; Wells, '13, etc.).

\section{Resistance to Low Concentration of Oxygen.}

As elsewhere shown in detail by the present writer (p. 741 of this Journal), if $\mathrm{pH}$ and other conditions are suitable, sticklebacks can live without any harm till the oxygen content of water goes down as low as 0.25-0.50 c.c. per litre. 
It appears that the power to withstand low pressures of oxygen is quite common amongst the freshwater fishes. Birge and Juday point out several cases in which a concentration of $1 \cdot 0$ c.c. per litre apparently did not prove dangerous to the individuals. Powers ('21) cites numerous authors to show that fishes do not suffer from oxygen want till its concentration reaches $1 \cdot 7-0 \cdot 4$ c.c. per litre.

\section{Course of Changes in the Physical and Chemical Condition of Water on the addition of Putrefying Substances.}

Observations on this subject, as mentioned above, are based on the decomposition of peptone, albumen, and casein, under both aerobic and anaerobic conditions. These substances were dissolved in Plymouth tap water $(\mathrm{pH}$ about $7 \cdot 0$ and alkali reserve $\cdot 0005 \mathrm{~N})$ in the proportion of 1 gram to a litre. The solutions subjected to aerobic conditions for the growth of bacteria were kept in wide shallow bowls of 6 litres capacity and were aerated at intervals of four hours in the daytime (9 am.-11 p.m.), no aeration being applied during the night. In the mornings, while traces of oxygen were often found in the solutions, the oxygen had sometimes been exhausted altogether. Winchester bottles were used for the solutions, which were kept out of contact with the atmosphere so that anaerobic putrefaction would proceed. All cultures were kept at room temperature, $65^{\circ}-70^{\circ} \mathrm{F}$.

\section{Hydrogen Ion Concentration, etc.}

The first noticeable result of decompesition is the production of $\mathrm{CO}_{2}$ and organic acids which increases the hydrogen ion concentration. As above mentioned, the aerobic solutions were aerated frequently, which naturally interfered with the normal course of $\mathrm{pH}$ change. Therefore to ascertain accurately the changes in this factor, two separate solutions of peptone and casein were kept undisturbed in bowls, 6 litres and 500 c.c. capacity respectively. The data obtained from these solutions are given in Table I, an examination of which will show that during the first three or four days the $\mathrm{pH}$ fell, being 6.5 (casein) at the end of that period. Then it began to rise steadily and went up to $8 \cdot 0$. After reaching this point, the $\mathrm{pH}$ fell again and remained about $7 \cdot 6$ till the experiments were discontinued at the end of the forty-fifth day. The course of these changes resembles closely that observed in the solutions (Table II) which were aerated frequently.

In the anaerobic solutions, as in the above, the $\mathrm{pH}$ went down during the first few days, and did so much more, reaching the figure $6 \cdot 0-6 \cdot 1$. Then it began to rise, but the rate of rise was much slower than that in the aerated solutions (Table II). 
The interesting point that the above account brings out is that the $\mathrm{pH}$ after falling for a short time begins to rise, suggesting thereby that basic substances are being produced in the putrefying solutions. As will be discussed at a later stage, this has a very significant bearing on the

\section{TABLE I.}

Course of Changes in $\mathrm{pH}$.

Solutions in wide shallow bowls. Undisturbed.

Room Temperature.

\begin{tabular}{|c|c|c|c|}
\hline $\begin{array}{l}\text { Age of } \\
\text { solution } \\
\text { in days. }\end{array}$ & $\begin{array}{l}\text { Peptone } \\
\text { pH. }\end{array}$ & $\begin{array}{c}\text { Casein } \\
\text { pH. }\end{array}$ & Remarks. \\
\hline 1 & $7 \cdot 15$ & & \\
\hline 2 & $6 \cdot 8$ & $6 \cdot 5$ & \\
\hline 3 & $6 \cdot 95$ & $7 \cdot 0$ & $\begin{array}{l}\text { Oxygen totally exhausted } \\
\text { in Casein solution. }\end{array}$ \\
\hline 4 & $7 \cdot 2$ & $7 \cdot 6$ & $\begin{array}{l}\text { Oxygen totally exhausted } \\
\text { in Peptone solution. }\end{array}$ \\
\hline 5 & $7 \cdot 3$ & $7 \cdot 65$ & \\
\hline 6 & $7 \cdot 4$ & $7 \cdot 75$ & \\
\hline 7 & $7 \cdot 45$ & $7 \cdot 8$ & \\
\hline 8 & $7 \cdot 5$ & $7 \cdot 9$ & \\
\hline 9 & $7 \cdot 55$ & $8 \cdot 0$ & \\
\hline 10 & $7 \cdot 55$ & $8 \cdot 0$ & \\
\hline 11 & $7 \cdot 65$ & $7 \cdot 7$ & \\
\hline 12 & $7 \cdot 7$ & $7 \cdot 65$ & \\
\hline 13 & & $7 \cdot 7$ & \\
\hline 14 & & $7 \cdot 8$ & \\
\hline 18 & $7 \cdot 7$ & $7 \cdot 65$ & \\
\hline 21 & $7 \cdot 65$ & $7 \cdot 7$ & \\
\hline 28 & $7 \cdot 75$ & $7 \cdot 7$ & \\
\hline 33 & $7 \cdot 8$ & & \\
\hline 45 & $7 \cdot 7$ & & \\
\hline
\end{tabular}

problem under investigation. The production of alkalinity during bacterial growth is a well-recognised phenomenon, Reddie ('23) having observed it in numerous cases.

The second point that may be emphasised in connection with the abovedescribed variation in hydrogen ion concentration is that the $\mathrm{pH}$ does not go much below $6 \cdot 0$, both in the aerated and anaerobic solutions. As the 
writer showed in the case of hay infusions ('26), the lowest $\mathrm{pH}$ that is reached in fermentations depends upon the alkali reserve of the water used, being minimum in the case of distilled water. The Plymouth tap water in having the low alkali reserve of $0.0005 \mathrm{~N}$ is almost similar to distilled water. Hence it is fair to conclude that in natural waters,

TABLE II.

Changes in pH in Aerobic and Anaerobic Solutions.

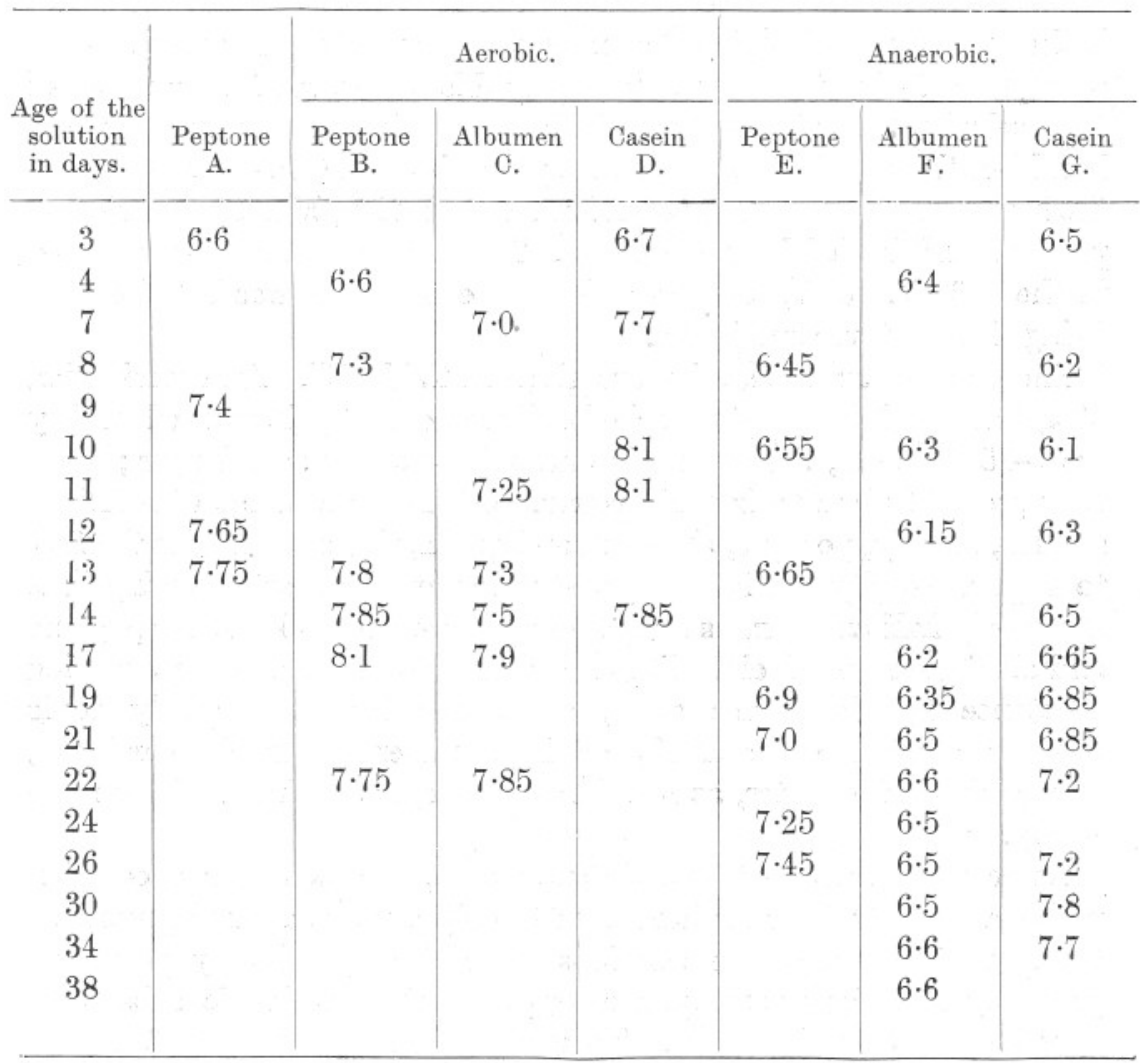

which invariably have some alkali reserve, the $\mathrm{pH}$ under similar conditions will not reach even $6 \cdot 0$.

\section{Oxygen Content.}

The changes in the oxygen content were also observed in the solutions kept undisturbed in wide bowls. The solutions when started had about 6.5 c.c. per litre of oxygen. There was a steady fall, and within three to four days the whole of the oxygen had been exhausted. When the supply 
of oxygen was renewed, as in the case of the aerated solutions, it was noticed that the rate of oxygen decrease was not greatest in the first few days, but after the expiry of about a week. Moreover, this rate was not the same in the different solutions, being far higher in the fermenting casein than in the others.

\section{Production of Toxic Substances.}

The last important change to be observed in the nature of the water is the appearance of toxic substances, which are obviously produced as a by-product of putrefaction. To study this factor, the killing power of each solution at different stages in its growth was ascertained after it had been thoroughly aerated and its $\mathrm{pH}$ adjusted at $7 \cdot 0-8 \cdot 0$, to exclude the harmful influence of hydrogen ion concentration, high carbon dioxide pressure, and the deficiency of oxygen. These experiments were performed in the 500 c.c. bowls, and generally each observation was based on the dying time of three specimens.

The data under this section are given in Table III. An examination of the same will show that the solutions become most poisonous when they are 7-15 days old, the anaerobic ones taking a few days longer; then they gradually lose their toxic power. Of the three kinds of solutions studied, namely, peptone, albumen, and casein, the last named is the first to acquire toxicity and becomes most poisonous, its shortest killing time being only half an hour, as compared with two and six hours for peptone and albumen respectively. It is interesting to add that the putrefying substance remaining the same, a solution becomes equally toxic whether aerated at intervals or kept under anaerobic condition, though under the latter, as mentioned above, it acquires toxicity more slowly.

As to the nature of the toxic substances, this is rather a complex problem and is left for further research, only a few remarks being made here. The fact that the solutions after becoming highly poisonous gradually lose their toxic power suggested that the toxic substances may be of a volatile nature. To verify this hypothesis the following experiments were performed: about 500 c.c. of the various solutions were boiled to half the volume, cooled, and water subsequently added to bring them to their original volume. Then they were aerated and their $\mathrm{pH}$ was adjusted at $7 \cdot 0-8 \cdot 0$. The killing power of the solutions so treated was ascertained. It was very much reduced; for example, the peptone solution which killed the fish in two hours before the above treatment, did so in twenty-five hours after it. In this connection it was also thought desirable to ascertain the effect of the distillates from solutions which had putrefied and were distilled in both alkaline $(\mathrm{pH} 8 \cdot 5)$ and acid $(\mathrm{pH} 4 \cdot 0)$ 
TABLE III.

Appearance of the Toxic Substances in the $0 \cdot 1 \%$ Solutions.

\begin{tabular}{|c|c|c|c|c|c|c|c|}
\hline \multirow{3}{*}{$\begin{array}{l}\text { Age of the } \\
\text { solution in } \\
\text { days. }\end{array}$} & \multicolumn{7}{|c|}{$\begin{array}{c}\text { Killing time in hours after thorough aeration and adjustment } \\
\text { of hydrogen ion concentration. }\end{array}$} \\
\hline & \multicolumn{4}{|c|}{ Aerobic. } & \multicolumn{3}{|c|}{ Anaerobic. } \\
\hline & \multicolumn{2}{|c|}{ A. Peptone ${ }^{2}$ B. } & \multirow[t]{2}{*}{$\begin{array}{l}\text { Albumen } \\
\text { C. }\end{array}$} & \multirow{2}{*}{$\frac{\begin{array}{c}\text { Casein } \\
\text { D. }\end{array}}{18}$} & \multirow[t]{2}{*}{$\begin{array}{l}\text { Peptone } \\
\text { E. }\end{array}$} & \multirow[t]{2}{*}{$\underset{\mathrm{F} .}{\text { Albumen }}$} & $\begin{array}{l}\text { Casein } \\
\text { G. }\end{array}$ \\
\hline 3 & 130 & & & & & & \\
\hline 4 & & 72 & 60 & & & 18 & \\
\hline 5 & & & & & & & \\
\hline 6 & & & & 2 & & 18 & \\
\hline 7 & & & 48 & $\frac{1}{2}$ & & & 5 \\
\hline 8 & & 72 & & $\frac{3}{4}$ & 30 & 20 & $\frac{1}{2}$ \\
\hline 9 & 12 & & & & 30 & & \\
\hline 10 & 3 & & & 6 & 30 & 20 & $\frac{1}{2}$ \\
\hline 11 & & & 48 & 7 & & & \\
\hline 12 & 2 & & & & & & \\
\hline 13 & $2 \frac{1}{2}$ & 12 & 18 & & 30 & & 1 \\
\hline 14 & & 3 & & & & & \\
\hline 15 & & & & & & & 3 \\
\hline 16 & & & & & & & \\
\hline 17 & & & 6 & & 28 & & \\
\hline 18 & & 6 & 9 & 10 & & 20 & \\
\hline 19 & & 7 & & & & & \\
\hline 20 & & & & & & 7 & \\
\hline 21 & & & & & & & \\
\hline 22 & & & & 15 & & 3 & \\
\hline 24 & & 10 & & & 18 & & \\
\hline 25 & & 11 & 10 & & & & \\
\hline 26 & & 11 & & & 9 & & \\
\hline 27 & & & 10 & & 4 & & \\
\hline 28 & & & & & & & \\
\hline 29 & & & & & & & \\
\hline 30 & & & & & 4 & & \\
\hline
\end{tabular}


conditions. In Table IV are given the killing times of the solutions (before distillation), of the residues and of the distillates. It will be observed that the residues in some cases are only very slightly toxic, while the distillates were decidedly toxic, although less so than the original putrefied solutions. They should have killed the fish almost instantly if all the toxic substances were volatile. This means that only some of the toxic substances are volatile, and that the residues lose the toxic power probably due to the mere action of heat. To examine this possibility some putrefied casein solution was heated at $70^{\circ} \mathrm{C}$. for twelve hours; after this treatment the solution did not kill the fish in six days even (when the experiment was stopped), while originally its killing power was only one hour.

The other fact that the above experiments reveal, and which is likely

TABLE IV.

\begin{tabular}{|c|c|c|c|c|}
\hline \multirow{2}{*}{$\begin{array}{l}\text { Putrefying } \\
\text { substance. }\end{array}$} & \multicolumn{3}{|c|}{ Killing time in hours. } & \multirow[b]{2}{*}{ Remarks. } \\
\hline & Solution. & Distillate. & Residue. & \\
\hline Peptone & 15 & 48 & 79 & $\begin{array}{l}\text { Distilled in alkaline con- } \\
\text { dition. }\end{array}$ \\
\hline Peptone & 3 & 5 & 60 & $\begin{array}{l}\text { Distilled in acid con- } \\
\text { dition. }\end{array}$ \\
\hline Casein & $\frac{1}{2}$ & 18 & 240 & Do. \\
\hline Casein & $\frac{3}{4}$ & 48 & 300 & $\begin{array}{l}\text { Distilled in alkaline con- } \\
\text { dition. }\end{array}$ \\
\hline Albumen & 6 & 12 & 60 & Do. \\
\hline
\end{tabular}

to have a bearing on the problem of the nature of the toxic substances, is that the stage of highest toxicity in the case of each putrefying solution was preceded by a period of rapid oxygen consumption.

\section{Relative Influence of Various Factors.}

After describing the optimum conditions and those that occur in water containing putrefying substances, some concluding remarks may be made as to the comparative significance of the various factors concerned.

The fact that $\mathrm{pH}$ does not go below 6.0 and that after falling for a short time begins to rise steadily, suggests strongly that hydrogen ion concentration as such has not got such a great importance in polluted waters as many investigators seem to think. On the other hand, carbon dioxide accumulates as has been described above. Sometimes, as in 
the case of solutions putrefying under anaerobic conditions, a high pressure of $\mathrm{CO}_{2}$ may occur sufficient to prove harmful to fish life, especially in still water. It is legitimate to emphasize its importance and urge the field worker to measure this gas even when the $\mathrm{pH}$ may be optimum.

All the infusions at some stage showed a high rate of oxygen consumption; therefore this gas, in spite of the fact that many freshwater fishes can withstand its low concentrations, is likely to be a factor of importance in polluted waters, especially in the bottom layers.

But the most important fact that the above experiments bring out is the great significance possessed by the toxic substances which appear as by-products of putrefaction, a factor hitherto almost ignored. Water containing any of the putrefying substance examined becomes highly toxic and kills the fish in $\frac{1}{2}-6$ hours, even when it is saturated with oxygen has an optimum $\mathrm{pH}$ and a low pressure of $\mathrm{CO}_{2}$. But, as has already been pointed out, the toxicity varies in the case of different substances, and it will therefore be a fruitful problem to investigate, from a comparative point of view, the toxicity resulting from the decomposition of various proteins, carbohydrates, etc., which are likely to be thrown in waters inhabited by food fishes. On the other hand, the problem of the nature of the toxic substances is bound to be of great interest to bio-chemists.

In conclusion, I must thank Dr. E. J. Allen, the Director of the Plymouth Laboratory, and Dr. W. R. G. Atkins, the head of the Physiological Department, who arranged for all the facilities for performing the experiments. My indebtedness is also due to Mr. H. W. Harvey of the same Laboratory, who took a keen interest in this investigation and made some valuable suggestions. Mr. H. O. Bull rendered me assistance in various ways, for which I am grateful.

\section{LITERATURE.}

Birge, E. A., And Juday, C. The Inland Lakes of Wisconsin. The dissolved gases of the water and their biological significance. Wisconsin Surv. Bulletin XXII, Madison, Wis. 1911.

Chidester, A. M. A critical examination of the evidence for physical and chemical influences on fish migration. Brit. Journ. Exper. Biology, II, p. 79. 1924.

Coker, R. E. Observations of hydrogen ion concentration in waters tributary to Catawba River, North Carolina. 1923.

Cole, A. E. Oxygen supply of certain animals living in water containing no dissolved oxygen. Journ. Exper. Zoo., 33, p. 292. 1921. 
Cole, A. E. Physiological Studies on freshwater clams. Carbon-dioxide production in low oxygen tensions. Journ. Exper. Zoo., 45, p. 349. 1921.

JAcoBs, M. H. To what extent are the physiological effects of carbon dioxide due to hydrogen ions? Amer. Journ. Physiol., 51, p. 321. 1920.

Jewell, M. E., And Brown, H. The fishes of an acid lake. Trans. Amer. Microscopical Soc., 43, p. 77. 1924.

Knauthe, K. Das Susswasser. Neudamm. 1907.

Knight, A. P. The effects of polluted waters on fish life. Contributions to Canadian Biology. Suppl. 32nd Annual Report Dept. of Marine and Fisheries, Ottawa. 1901.

Marsh, M. C. House Document, Vol. 64, U.S. Geol. Survey Water Supply and Irrigation Papers, No. 192, pp. 337-349.

Marsh, M. C. Notes on the dissolved content of water in its effect upon fishes. Bull. Bureau Fisheries, 28, p. 893. 1908.

Matthews, A. P. The relation between solution-tension, atomic volume, and the physiological action of the elements. Amer. Journ. Physiol., 10, p. 290. 1904.

Powers, E. B. Experiments and observations on the behaviour of marine fishes toward hydrogen ion concentration of the sea water in relation to their migratory movements and habits. Publ. Puget Sound Biol. Station, 3, p. 1. 1921.

Reddie, J. A. Journ. Soc. Chem. Ind., 1923, p. 326T.

Roberts, C. H. Oil Pollution. Journ. Conseil Internat. pour Exploration de la mer, I, p. 245. 1926.

Roule, L. Observations comparative sur la proportion d'oxygène dissous dans les eaux d'un étang littoral (Étang de Thau) et dans les eaux marine littorales, et sur ces conséquences quant à la biologie des espèces migratrices des Poissons. C.R. Soc. Biol., "79, p. 434. 1916.

Shelford, V. E., AND Allee, W. C. The reaction of fishes to gradients of dissolved atmospheric gases. Journ. Exper. Zoo., 14, p. 207. 1913.

SHelford, V. E. An experimental study of the effects of gas waste upon fishes, with special reference to stream pollution. Bull. Ill. State Lab. Nat. Hist., 11, p. 381. 1917.

Shelford, V. E. Ways and means of measuring the dangers of pollution to fisheries. Bull Ill. State Lab. Nat. Hist., 13, p. 25. 1918. 
Shelford, V. E. The relation of marine fishes to acids with particular reference to the Miles Acid Process of sewage treatment. Publ. Puget Sound Biol. Station, 2, p. 97. 1918.

Singh Pruthi, H.

Brit. Journ. Exp. Biol., 4 (in press).

Singh Pruthi, H. The ability of fishes to extract oxygen at different hydrogen ion concentrations of the medium. Journ. Mar. Biol. Assoc., Vol. XIV, N.S., No. 3, 1927.

Suter and Moore. Stream pollution studies. New York State Conservation Commission. 1922.

WeLLs, M. M. The resistance of fishes to different concentrations and combinations of carbon dioxide and oxygen. Biol. Bull., 25, pp. 323-347. 1913.

WeLLS, M. M. The reactions and resistance of fishes in their natural environment to salts. Journ. Experml. Zoo., 19, pp. 243-283. 1915.

WELLS, M. M. The reactions and resistance of fishes in their natural environment to acidity, alkalinity, and neutrality. Biol. Bull. 29, pp. 221-257. 1915.

WelLS, M. M. The reaction and resistance of fishes to carbon dioxide and carbon monoxide. Bull. Ill. State Lab. Nat. Hist., 11, p. 557. 1918.

Wundsch, H. H. Die reinhaltung unserer Fishgewässer. Handbuch der Binnenfischerei Mitteleuropas, 6, pp. 139-221. 1926. 
